\title{
FIKSASI TULANG DENGAN ALAT BERBAHAN DASAR POLIMER (Uji Biokompatibilitas)
}

\author{
Mochammad Taha Ma'ruf \\ Bagian Ilmu Bedah Mulut, FKG Universitas Mahasaraswati, Denpasar \\ E-mail: tahamaaruf@gmail.com
}

\begin{abstract}
Bone fracture fixation device have been using rigid metallic materials such as titanium, titanium-alloy or cobalt chrome. Besides having some advantages, as the titanium fixation devices also have disadvantages. It is challenge to develop the use of polymeric materials have good biocompatibility and mechanical strength appropriate to have a bone fracture fixation devices that can be absorbed by the body, such as Polyvinyl Alcohol (PVA). The purpose of this study is to know whether the PVA-HA composite with catgut reinforced has good biocompatibility without toxicity and hypersensitivity effects in experimental animals. Biocompatibility testing include local cytotoxicity and type IV contact hypersensitivity test using wistar rats (Rattus norvegicus). Testing is done through two phases, induction or sensitization phase is by rubbing PVA-HA composite with catgut reinforced ointment puder on the ears. Local toxicity testing is done by implantation of PVA-HA composite with catgut reinforced on the back catgut wistar rats. The results showed no discoloration or induration on animal ears in all treatment and control groups on the sensitization and the elicitation phase. There were no significant differences of the thickness of the wistar rats ears from all treatment groups before and after treatment on measures 24, 48 and 72 hours $(\rho>0.05)$. Microscopic examination showed no infiltration of acute inflammatory cells such as neutrophils, basophils or eusinofil and chronic inflammatory cell infiltration such as macrophages, lymphocytes and plasma cells. It can be concluded that the PVA-HA (60:40)composite with catgut reinforced is a material that does not cause toxicity and hypersensitivity in experimental animals, thus potentially be used as bone fractures fixation material.
\end{abstract}

Keywords : biocompatibility, bone fractures, polyvinyl alcohol, hydroxyapatite

\section{PENDAHULUAN}

Biokompatibilitas merupakan kemampuan suatu material untuk berinteraksi dengan sel-sel / jaringan hidup atau sistem metabolisme yang tidak menyebabkan toksisitas, injuri atau reaksi imun saat berfungsi pada tempat spesifik. ${ }^{1}$ Biokompatibilitas menentukan apakah bahan tersebut dapat digunakan di dalam tubuh, di samping sifat secara fisik dan kimia, kemudahan proses, estetika dan harga yang terjangkau. Secara umum, biokompatibilitas dapat diukur berdasarkan sitotoksisitas setempat, sistemik dan kemampuan menimbulkan alergi serta karsinogenik. ${ }^{2}$ Tujuan dari uji biokompatibilitas adalah untuk mengetahui interaksi antara material terhadap jaringan tubuh. ${ }^{3}$ Respon inflamasi ditunjukkan dengan meningkatnya jumlah sel neutrofil terutama di bagian tepi dari jaringan yang mengalami reaksi toksisitas, ${ }^{4}$ sedangkan reaksi atau respon imun akan terjadi apabila terdapat penolakan terhadap bahan implan berupa reaksi hipersensitivitas. ${ }^{5}$

Alat fiksasi patah tulang selama ini menggunakan material dari bahan logam seperti titanium, titanium-alloy atau cobalt chrome. Kekuatan dan kekakuan titanium yang terlalu tinggi dibandingkan dengan tulang yang patah menyebabkan stimulus tulang terus menerus. Kondisi ini menyebabkan terjadinya atropi tulang di bawah plat, yang selanjutnya menganggu pertumbuhan tulang terutama pada anakanak. ${ }^{6,7}$ Kekurangan lain material logam lainnya adalah bahan ini dapat terlihat atau teraba secara visual, sekrup mudah longgar atau terlepas, sensitif terhadap suhu, dan merupakan penghalang pada terapi radiasi. ${ }^{10,11}$ Penelitian selanjutnya juga menunjukkan bahwa bahan ini menyebabkan penyebaran ion-ion logam pada kelenjar limfe regional (lymph nodes) dan sering menimbulkan reaksi alergi. ${ }^{12}$ Beberapa kekurangan tersebut menyebabkan perlunya dilakukan operasi sekunder untuk pengambilan kembali alat fiksasi ini, yang menyebabkan peningkatan waktu dan biaya perawatan.

Untuk menghindari operasi sekunder dikembangkan penggunaan bahan polimer yang bisa diserap tubuh, ${ }^{10,13}$ pada penelitian ini digunakan Polivinil Alkohol (PVA). Material ini sebelumnya telah banyak digunakan untuk menggantikan jaringan tubuh yang mengalami kerusakan atau penyakit karena memiliki sifat fisikokemikal terutama sifat biotribological yang sangat baik yaitu memiliki permukaan licin, tahan terhadap gesekan dan keausan. ${ }^{14,15}$ Bahan ini diketahui memiliki biokompatibilitas yang sangat baik sehingga telah digunakan pada beberapa aplikasi biomedis seperti drug delivery, lensa kontak, graf tulang, penutup luka dan jaringan lunak sendi lutut. ${ }^{16,17,18}$ PVA memiliki karakteristik mekanis yang rendah, sehingga selama ini diaplikasikan hanya pada tempat yang tidak membutuhkan kekuatan mekanis yang tinggi.

Penelitian sebelumnya ${ }^{19}$, PVA dikompositkan dengan beberapa material untuk meningkatkan karakteristik mekanisnya. Penelitian tersebut menggunakan hidroksiapatit (HA) bovine sebagai bahan pengisi (filler), anyaman catgut (bioresorbable suture) sebagai penguat (reinforcement), dan glutaraldehid sebagai crosslinker. Hidroksiapatit merupakan bahan bioaktif, osteokonduktif serta memiliki biokompatibilitas yang baik. ${ }^{20}$ Penelitian sebelumnya menunjukkan bahwa komposit PVA-HA (60:40) dengan penguat catgut memiliki kekuatan mekanis yang cukup dan stabil sebagai bahan penyambung patah 
tulang. ${ }^{19}$ Tujuan penelitian ini adalah ingin mengetahui apakah komposit PVA-HA (60:40) dengan penguat catgut memiliki biokompabilitas yang baik tanpa menimbulkan efek toksisitas dan hipersensitivitas pada hewan coba, sehingga dapat digunakan sebagai bahan penyambung patah tulang.

\section{BAHAN DAN METODE}

\section{A. Pembuatan Spesimen Komposit}

Pembuatan spesimen dilakukan dengan cara sebagai berikut. ${ }^{19}$ Serbuk PVA dan HA ditimbang masing-masing sesuai dengan proporsinya. PVA dilarutkan dalam akuades dengan perbandingan 7,5\% $(w / v)$, dipanaskan pada suhu $95{ }^{\circ} \mathrm{C}$ dengan 600 putaran permenit (rpm) selama 30 menit. Setelah PVA larut, ditambahkan HA sesuai perbandingan kelompoknya, diaduk dengan mesin stirer dan dipanaskan pada suhu $60{ }^{\circ} \mathrm{C}$ dengan putaran $600 \mathrm{rpm}$ selama 60 menit. Proses lay up dilakukan selapis demi lapis pada cetakan yang sudah diberi lapisan anyaman benang catgut, dipanaskan menggunakan oven pada suhu $70{ }^{\circ} \mathrm{C}$ selama 15 menit. Dilakukan proses lay up dan pemanasan selanjutnya sampai jumlah layer dan ketebalan yang diinginkan. Setelah cetakan penuh, dipanaskan menggunakan oven pada suhu $70{ }^{\circ} \mathrm{C}$ selama 2 jam. Setelah dingin, spesimen dikeluarkan dari cetakan dan dipanaskan menggunakan oven pada suhu $70{ }^{\circ} \mathrm{C}$ selama 2 jam.

\section{B. Uji Hipersensitivitas Kontak Tipe IV (Patch Tes)}

Spesimen komposit PVA-HA (60:40) dengan penguat catgut dipotong dan digerus menggunakan wadah keramik (mortal) sampai halus. Serbuk yang sudah halus ditimbang menggunakan timbangan digital dan dicampur dengan vaselin menggunakan mortal sesuai konsentrasi masing-masing. Setelah didapatkan konsentrasi serbuk dalam vaselin $2,5 \%$; $5 \%$ dan $10 \%$, salep dimasukkan dalam botol plastik tertutup dan diberi tanda.

Jenis penelitian adalah eksperimental laboratorium in vivo. Subjek penelitian menggunakan 20 ekor tikus putih galur Wistar (Rattus norvegicus), jenis kelamin betina, umur 3 bulan dan berat 200-250 gram. Rancangan penelitian terdiri dari 3 (tiga) kelompok perlakuan dan 1 (satu) kelompok kontrol, masing-masing terdiri dari 5 (lima) ekor. Kelompok perlakuan dibedakan berdasarkan konsentrasi komposit PVA-HA (60:40) dengan penguat catgut terhadap salep vaselin yaitu $2,5 \%$, 5\% dan $10 \%$. Kelompok kontrol mengandung salep vaselin saja. Sampel penelitian adalah kulit punggung dan telinga tikus putih galur Wistar. Pengujian dilakukan melalui dua tahap, tahap induksi atau sensitisasi berlangsung sampai dengan 10 hari. Setelah diistirahatkan selama 3 hari, dilanjutkan kontak tahap kedua (elisitasi) pada hari ke 14 dan diamati pada periode 24, 48, dan 72 jam.

Tikus putih galur Wistar (Rattus norvegicus) 20 ekor dibagi menjadi 4 kelompok, masing-masing terdiri dari 5 ekor. Semua hewan coba dibius dengan ketamin 0,2 cc dan dicukur pada kulit punggungnya. Kelompok I (kontrol) diolesi bahan dasar salep (vaselin) pada kulit punggung (Gambar 1.a), kemudian dibalut dengan plester dengan lebar $2,5 \mathrm{~cm}$. Kelompok II, III, IV, diolesi salep puder komposit PVA-HA (60:40) dengan penguat catgut dengan konsentrasi berturut-turut 2,5\%, $5 \%$ dan $10 \%$, kemudian dibalut dengan plester selebar 2,5 cm. Plester dibuka setelah 10 hari. Setelah diistirahatkan selama 3 hari, kemudian pada hari ke 14 dilakukan kontak tahap kedua (elisitasi) yaitu dengan pengolesan salep puder komposit PVA-HA (60:40) dengan penguat catgut sesuai kelompoknya pada daun telinga (Gambar 1.b). Sebelum diolesi salep, dilakukan pengamatan secara makroskopis dan ketebalan telinga diukur dengan mikrometer.

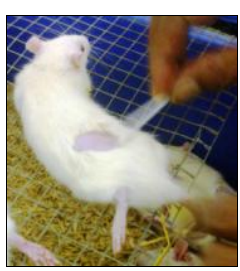

(a)

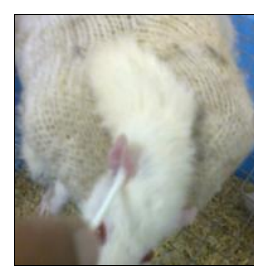

(b)

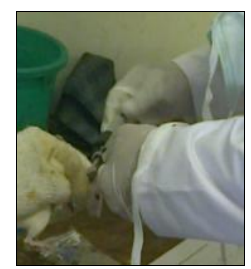

(c)
Gambar 1. (a) Pengolesan salep pada tahap elisitasi; (b) Pengolesan salep pada telinga luar; (c) Pengukuran telinga dengan mikrometer

Pada periode waktu 24, 48, dan 72 jam dilakukan pengamatan makroskopis pada telinga hewan coba dan dilakukan pengukuran ketebalan telinga menggunakan mikrometer (Gambar 1.c). Hasil pengamatan makroskopis dicatat dengan cara pemberian skor 0-2, yaitu: 0 (tidak ada tanda merah); 0,5 (warna pink/merah muda); 1 (warna merah merata); 2 (benjolan warna merah); ${ }^{21}$ selanjutnya dilakukan analisis data menggunakan uji statistik ANOVA satu jalan.

\section{Uji Toksisitas Setempat}

Uji toksisitas setempat dilakukan dengan cara penanaman (implantasi) potongan komposit PVA-HA (60:40) dengan penguat catgut pada kulit punggung tikus putih galur Wistar. Selanjutnya dalam periode waktu tertentu, bahan implan dibuka dan dilakukan pemeriksaan kulit punggung tikus secara histologis dan diamati di bawah mikroskop cahaya.

Jenis penelitian adalah eksperimental laboratorium in vivo. Subjek penelitian adalah 8 (delapan) ekor tikus putih galur wistar (Rattus norvegicus). Sampel penelitian adalah kulit punggung tikus putih galur Wistar. Rancangan penelitian terdiri dari 1 (satu) kelompok perlakuan dan 1 (satu) kelompok kontrol, masing-masing berjumlah 5 ekor (lima) ekor. Kelompok perlakuan adalah kelompok yang diimplankan potongan komposit PVA-HA (60:40) dengan penguat catgut berukuran $0,5 \times 0,5 \times 0,5 \mathrm{~cm}$ di bawah kulit (subkutan) punggung tikus putih galur Wistar. Kelompok kontrol adalah kelompok tikus tanpa dipasang implan.

Lima hewan coba dibius dengan ketamin $100 \mathrm{mg}$ sebanyak 0,2 ml. Kulit punggung hewan coba dicukur berukuran $2 \times 2 \mathrm{~cm}$ dan diinsisi pada bagian kulitnya. Potongan komposit PVA-HA (60:40) dengan penguat catgut berukuran $0,5 \times 0,5 \times 0,5 \mathrm{~cm}$ dimplankan di bawah kulit (subkutan) punggung hewan coba dan dilakukan penjahitan luka (Gambar 2.a). Setelah 5 hari, hewan coba didekapitasi. Kulit punggung hewan coba dipotong 
(eksisi) berukuran 2,5x2,5 cm (Gambar 2.b) dan di simpan dalam wadah berisi cairan fiksatif (PBS 10\% dan formalin). Selanjutnya dilakukan prosedur pemeriksaan histologis yang meliputi pembuatan blok parafin, pengirisan dengan mikrotom dan pewarnaan dengan hemaktosilin eosin (HE). Pengamatan slide dilakukan dengan menggunakan mikroskop cahaya Olymphus $^{\circledR}$ dengan pembesaran 40 kali. Hasil pengamatan diproses dan ditampilkan menggunakan optilab® viewer 2.1.

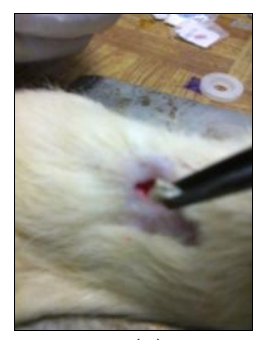

(a)

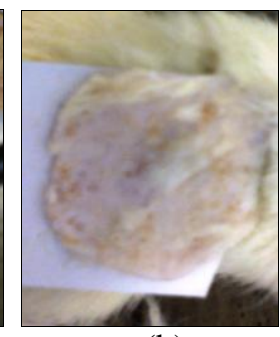

(b)
Gambar 2. Proses uji toksisitas setempat (a) Insisi pada kulit punggung dan penanaman implan; (b) Eksisi kulit punggung setelah 5 hari

\section{HASIL DAN DISKUSI}

\section{Uji Hipersensitivitas Kontak Tipe IV (Patch Test)}

Pengujian dengan metode patch test dilakukan dalam dua tahap yaitu tahap sensitisasi dan elisitasi. Tahap sensitisasi dilakukan dengan cara kontak tahap pertama yang berlangsung sampai dengan 10 hari, dilanjutkan dengan kontak tahap kedua (tahap elisitasi) pada hari ke 14 setelah diistirahatkan selama 3 hari. Pengamatan dilakukan pada 24, 48 dan 72 jam setelah kontak tahap kedua tersebut, dengan melihat adanya perubahan bentuk dan warna daun telinga hewan coba secara makroskopis serta adanya penebalan telinga. Tabel 1 menampilkan tabulasi pengamatan secara makroskopis perubahan bentuk dan warna telinga tikus putih pada tahap sensitisasi dan elisitasi.

Tabel 1. Pengamatan makroskopis telinga tikus putih tahap sensitisasi dan elisitasi $(n=5)$

\begin{tabular}{l|cccc}
\hline \multirow{2}{*}{ Klp } & Hari ke 10 & 24 jam & $\mathbf{4 8}$ jam & 72 jam \\
\cline { 2 - 5 } & Skor & Skor & Skor & Skor \\
\hline P1 & 0 & 0 & 0 & 0 \\
P2 & 0 & 0 & 0 & 0 \\
P3 & 0 & 0 & 0 & 0 \\
K & 0 & 0 & 0 & 0 \\
\hline Ket : & P1(kelompok tikus putih yang mendapat paparan salep \\
& 2,5\%, P2(kelompok tikus putih yang mendapat \\
paparan salep 5\%, P3(kelompok tikus putih yang \\
mendapat paparan salep 10\%, K(kelompok tikus putih \\
yang mendapat paparan salep vaselin saja)
\end{tabular}

Setelah dilakukan pengamatan secara makroskopis, dilakukan pengukuran ketebalan telinga tikus putih dengan menggunakan mikrometer. Data ketebalan telinga yang dicatat pada periode 24,48 , dan 72 jam setelah tahap elisitasi dibandingkan dengan data ketebalan telinga sebelum perlakuan dan kelompok kontrol. Tabel 2 menampilkan rerata dan simpang baku ketebalan telinga tikus putih sebelum dan sesudah perlakuan.

Tabel 2. Rerata dan simpang baku ketebalan telinga tikus putih sebelum dan sesudah pemaparan salep puder komposit PVA-HA (60:40) dengan penguat catgut $(\mathrm{n}=5)$

\begin{tabular}{l|cccc}
\hline \multirow{2}{*}{ Klp } & Sebelum & $\mathbf{2 4}$ jam & $\mathbf{4 8 ~ j a m ~}$ & $\mathbf{7 2}$ jam \\
\cline { 2 - 5 } & $\begin{array}{c}\text { Tebal } \\
(\mathbf{m m})\end{array}$ & $\begin{array}{c}\text { Tebal } \\
(\mathbf{m m})\end{array}$ & $\begin{array}{c}\text { Tebal } \\
(\mathbf{m m})\end{array}$ & $\begin{array}{c}\text { Tebal } \\
(\mathbf{m m})\end{array}$ \\
\hline P1 & $0,40 \pm 0,05$ & $0,43 \pm 0,05$ & $0,45 \pm 0,04$ & $0,45 \pm 0,01$ \\
P2 & $0,45 \pm 0,03$ & $0,47 \pm 0,03$ & $0,46 \pm 0,03$ & $0,45 \pm 0,03$ \\
P3 & $0,43 \pm 0,02$ & $0,46 \pm 0,02$ & $0,47 \pm 0,01$ & $0,44 \pm 0,01$ \\
K & $0,44 \pm 0,06$ & $0,48 \pm 0,05$ & $0,47 \pm 0,05$ & $0,47 \pm 0,05$ \\
\hline
\end{tabular}

Ket: P1(kelompok tikus putih yang mendapat paparan salep 2,5\%, P2(kelompok tikus putih yang mendapat paparan salep 5\%, P3(kelompok tikus putih yang mendapat paparan salep $10 \%, \mathrm{~K}$ (kelompok tikus putih yang mendapat paparan salep vaselin)

Hasil uji hipersensitivitas kontak dengan cara pengamatan secara makroskopis menunjukkan tidak adanya perubahan warna ataupun benjolan pada telinga hewan coba pada semua kelompok perlakuan dan kontrol pada tahapan sensitisasi maupun tahapan elisitasi (Tabel 1). Hasil uji juga menunjukkan rerata ketebalan telinga yang relatif sama pada semua kelompok perlakuan dan kontrol pada tahapan sensitisasi maupun tahapan elisitasi (Tabel 2). Uji Anava Satu Jalan menunjukkan tidak terdapat pengaruh dosis salep puder PVA-HA (60:40) dengan penguat catgut $(2,5 \%, 5 \%$ dan $10 \%)$ terhadap penebalan telinga hewan coba pada pengukuran periode 24,48 dan 72 jam $(p>0,05)$. Hal ini menunjukkan bahwa polimer PVA, hidroksiapatit, catgut dan glutaraldehid secara individu atau dalam bentuk komposit tidak bersifat imunogenik.

Hipersensitivitas kontak tipe IV adalah reaksi tipe yang tidak diperantarai oleh antibodi tetapi oleh sel $\mathrm{T}$ yang bersifat spesifik antigen. Aktivasi kelompok sel $\mathrm{T}$ tertentu di dalam organ limpoid akan menyebabkan lepasnya Ag-binding factor. Selanjutnya Ag-binding factor akan mengaktivasi sel mast untuk menghasilkan serotonin yang mengakibatnya naiknya permeabilitas pembuluh darah, sehingga sel $\mathrm{T}$ spesifik antigen keluar dari pembuluh darah menuju jaringan. ${ }^{22}$ Pada tahap induksi, terjadi kontak antara alergen (hapten) dengan komponen kulit. Hapten dan protein kulit berikatan membentuk komplek hapten-carrier. Molekul alergen diekspresikan ke permukaan sel dalam bentuk ikatan dengan molekul major histocompatibility complex (MHC) klas II yang terdapat pada antigen presenting cells (APC). ${ }^{23}$ Selanjutnya bila terjadi kontak ulang dengan antigen, sel $\mathrm{T}$ efektor yang spesifik antigen akan menghasilkan limfokin yang bersifat kemotaktik sehingga terjadi infiltrasi sel-sel inflamasi yang menimbulkan adanya gambaran kemerahan (erythema) dan penonjolan (indurasi) pada tempat terjadinya reaksi tersebut. $^{21,22,23}$

Pemaparan salep puder komposit PVA-HA (60:40) dengan penguat catgut tidak menyebabkan terjadinya ikatan dengan komponen protein pada kulit. Kondisi ini menyebabkan tidak terbentuknya kompleks hapten carrier, menyebabkan tidak terjadinya ikatan dengan MHC klas II yang dimiliki oleh sel Langerhans epidermis. Dengan demikian, tidak terjadi reaksi 
hipersensitivitas pada fase induksi ataupun fase elisitasi. Kondisi ini menunjukkan bahwa komposit PVA-HA (60:40) dengan penguat catgut tidak menyebabkan reaksi hipersensitivitas kontak tipe IV pada hewan coba.

\section{Uji Toksisitas Setempat}

Uji toksisitas setempat dilakukan dengan cara penanaman potongan komposit PVA-HA (60:40) dengan penguat catgut pada kulit punggung tikus putih galur Wistar. Pada hari ke-6, bahan implan dibuka dan dilakukan pemeriksaan kulit punggung tikus secara histologis dan diamati di bawah mikroskop cahaya. Pemeriksaan yang sama juga dilakukan pada kelompok kontrol yaitu kelompok tikus tanpa dipasang implan. Gambar 3 menampilkan gambaran histologis potongan jaringan kulit punggung tikus pada kelompok perlakuan dan kontrol tersebut.

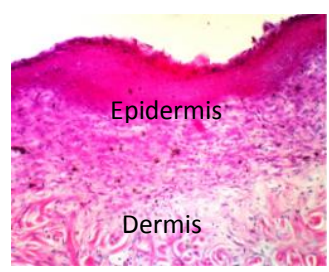

(a)

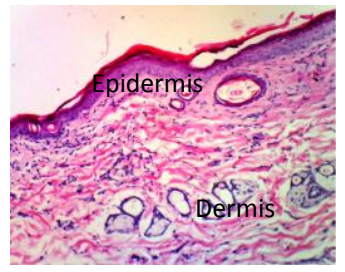

(b)
Gambar 3. Gambaran mikroskopis jaringan kulit punggung tikus setelah implantasi (a) Kelompok Perlakuan dan (b) Kelompok Kontrol (perbesaran 40 x)

Gambaran histologis potongan jaringan kulit punggung tikus putih pada kelompok perlakuan dan kontrol menunjukkan gambaran lapisan epidermis dan dermis normal (Gambar 3). Tidak tampak adanya infiltrasi sel radang akut seperti neutrofil, eusinofil dan basofil ataupun infiltrasi sel radang kronis seperti makrofag, limposit dan sel plasma. Kondisi tersebut menunjukkan bahwa komposit PVA-HA (60:40) dengan penguat catgut tidak menyebabkan reaksi toksisitas setempat yang ditandai dengan tidak adanya infiltrasi sel radang.

Suatu material dapat menimbulkan efek toksik jika material tersebut berhubungan langsung dengan sel atau jaringan sasaran. ${ }^{24}$ Material toksik harus menembus membran yang melindungi makhluk hidup (organisme) dari pengaruh luar untuk dapat menimbulkan suatu efek toksik. Perpindahan zat toksik dari satu bagian tubuh dengan cara menembus beberapa membran biologik yang terjadi pada proses absorbsi, distribusi, dan ekskresi. $^{25}$ Alat fiksasi patah tulang rahang dipasang untuk memfiksasi kedua sisi tulang yang patah, sehingga akan kontak langsung dengan tulang pada sisi dalam dan gusi pada sisi luar. Material yang kontak tersebut dapat menyebabkan lepasnya mediator kimia dan faktor-faktor pertumbuhan sehingga menimbulkan reaksi keradangan sekitar plat tersebut. Implantasi material tersebut menyebabkan terjadinya reaksi tubuh terhadap benda asing, dimulai dari respon inflamasi akut, bahkan pada beberapa kasus dapat menyebabkan terjadinya respon inflamasi kronis, yaitu terbentuknya jaringan granulasi dan kapsul fibrus. ${ }^{26}$ Lama dan intensitas masing-masing respon ini tergantung atas luasnya injuri yang terjadi pada implantasi, komposisi kimia material, bentuk permukaan, porositas, kekasaran, bentuk dan ukuran implan. ${ }^{27}$

Reaksi toksisitas akut, diawali dengan adanya respon inflamasi pada jaringan dan secara morfologi menunjukkan gambaran sel yang membengkak, terjadi denaturasi protein dan hidrolisis, serta hilangnya komponen sel. ${ }^{28}$ Inflamasi berupa respon protektif tubuh terhadap trauma atau benda asing yang berbahaya dengan gejala lima tanda radang yang ditetapkan oleh Cornelius Celsus antara lain: yaitu sakit (dolor), panas (calor), merah (rubor), bengkak (tumor), dan hilangnya fungsi (functiolaesa). ${ }^{29,30}$ Tanda-tanda tersebut di atas dijumpai pada kondisi radang akut, namun pada radang kronis bila fokus-fokus radang sudah mulai berkurang, tanda-tanda tersebut akan menghilang. ${ }^{31}$

\section{SIMPULAN}

Dari hasil penelitian dan pembahasan di atas dapat disimpulkan bahwa komposit PVA-HA (60:40) dengan penguat catgut merupakan bahan yang biokompatibel tanpa menimbulkan efek toksisitas dan hipersensitivitas pada hewan coba, sehingga berpotensi digunakan sebagai bahan penyambung patah tulang.

\section{DAFTAR PUSTAKA}

1. Bumgardner JD, Vasquez-Lee M, Fulzele K, Smith D, Branch K, Christian SI. Biocompatibility Testing. In: Williams DL. Encyclopedia of Biomaterials and Biomedical Engineering, $2^{\text {nd }}$ ed.; 2008. h. 169-178

2. Anusavice KJ. Phillips'Science of Dental Materials, $8^{\text {th }}$ ed., St. Louis, Missouri, USA: Saunders Co.; 2003.

3. Williams D. Concise Encyclopedia of Medical and Dental Materials. United Kingdom: Pergamon Press; 1990. h. 87-93.

4. Robbins SL and Anggel M. Basic Pathology, $2^{\text {nd }}$ ed., Philadelphia: W.B. Saunders Co.; 1976, h. 2144.

5. Roitt I, Brostoff J, and Male D. Immunology $5^{\text {th }}$ ed., London: Mosby International Limited; 1998. h. 302-348.

6. Brodke DS, Gollogly S, Alexander, Mohr R, Nguyen BK, Dailey AT and Bachus aK. Dynamic cervical plates: biomechanical evaluation of load sharing and stiffness. Spine 2001; 26(12): 1324 1329.

7. Kennady MC, Tucker MR, Lester GE and Buckley MJ. Histomorfometric evaluation of stress shielding in mandibular continuity defects treated with rigid fixation plates and bone grafts. Int $J$ Oral Maxillofac Surg. 1989; 18: 170-174.

8. Goodship V dan Jacobs D. Polyvinyl alcohol: Materials, procesing and applications, review reports, Rapra Review Reports 2005; 16(12): 3-24.

9. Bessho K, Fujimura K dan Iizuka T. Experimental long-term study of titanium ions eluted from pure titanium miniplates. J Biomed Mater Res. 1995; 29: 901-904.

10. Mazzonetto R, Paza AO and Spagnoli DB. A retrospective evaluation of rigid fixation in orthognathic surgery using a biodegradable self- 
reinforced (70L:30DL) polylactide. Int $J$ Oral Maxillofac Surg. 2004; 33: 664-669.

11. Scher N, Poe D, Kuchmir F, Reft C, Weichselbaum R and Panje WR. Radiotherapy of the selected mandible following stainless steel plate fixation. Laryngoscope, 1988; 98: 561-563.

12. Jorgenson DS, Mayer MH, Ellenbogen RG, Centeno JA, Johnson FB and Mullick FG. Detection of titanium in human tissues after craniofacial surgery. Plast Reconstr Surg. 1997; 99: 976-979.

13. Yerit KC, Enislidis G, Schoppe RC, Turhani D, Wanschitz $F$ and Wagner A. Fixation of mandibular fractures with biodegradable plate and screw. Oral Surg Oral Med Oral Pathol Oral Radiol Endod. 2002; 94: 294-300.

14. Suciu AN, Iwatsubo T and Matsuda M. A study upon durability of the artificial knee joint with PVA hydrogel cartilage. JSME 47(1) Part C; 2004. h. 199-208.

15. Stammen S, Williams JA and Ku DN. Mechanical properties of a novel PVA hydrogel in shear and unconfined compression. Biomaterials 2001; 22: 799-806.

16. Pan YS, Xiong DS and Ma RY. A study on the friction properties of poly(vinyl alcohol) hydrogel as articular cartilage against titanium alloy. Wear 2007; 262: 1021-1025.

17. Kobayashi M, Chang YS and Oka MA. Two year in vivo study of polyvinyl alcohol-hydrogel (PVAH) artificial meniscus. Biomaterials 2005; 26: 3243-3248.

18. Peppas NA and Merrill EW. Development of semicrystalline poly(vinyl alcohol) hydrogels for biomedical application. J Biomed Mater Res. 1997; 11: 423-434.

19. Ma'ruf T, Siswomihardjo W, Soesatyo MHNE and Tontowi AE. Polyvinyl Alcohol - Hydroxyapatite Composite Reinforced with Catgut Fibers as Biodegradable Bone Plates. Prosiding pada International Conference on Instrumentation, Communication, Information Technology and Biomedical Engineering; 2013. Bandung, Indonesia.
20. Suchanek W and Yoshimura MJ. Processing and properties of hydroxyapatite based biomaterials for use as hard tissue replacement implants, Mater Res. 1998; 13: 94.

21. Holgate ST and Church MK. Allergy. New York, USA: Gower Medical Publishing; 1993. h. 211281.

22. Bellanti JA. Immunology III (terjemahan). Yogyakarta: Gadjah Mada University Press; 1993. h. 173-202.

23. Roeslan BO. Imunologi Oral: Kelainan di Dalam Rongga Mulut. Jakarta: Balai Penerbit Fakultas Kedokteran Universitas Indonesia; 2002.

24. Shayne CG and Christopher PC. Acute Toxicology Testing, $2^{\text {nd }}$ ed. London: Academic Press; 1998. h. 244-255.

25. Ngatijan. Toksikologi: Racun, Keracunan, dan Terapi Keracunan. Yogyakarta: Bagian Farmakologi dan Toksikologi Fakultas Kedokteran UGM; 2006. h. 6-44.

26. Sharma CP. Biomaterials and artificial organs: Few challenging areas. Trends Biomater. Artif. Organs 2005; 18(2): 148-157.

27. Li Y, Schutte RJ, Abu-Shakra A and Reichert WM. Protein array method for assessing in vitro biomaterials-induced cytokine expression. Biomaterials. 26(10); 2005. h. 1081-1085.

28. Nicholson JW. The Chemistry of Medical and Dental Materials, R.S.C. Cambridge; 2002. h. 186-221.

29. Sudiono J, Kurniadi B, Hendrawan A dan Djimantoro B. Ilmu Patologi, Sudiono J dan Yuwono L (penterjemah). Jakarta: EGC; 2003. h. 81-96.

30. Baratawidjaya KG dan Rengganis I. Imunologi Dasar, $9^{\text {th }}$ ed., Jakarta: FKG UI; 2010.

31. Mitchell RN and Cotran RS. Acute and chronic inflammation. In: Robbins SL and Kumar V. Basic Pathology. $7^{\text {th }}$ ed., Philadelphia: Elsevier Saunders; 2003. h. 33-59.

32. Bowless WH, Tardy SJ, Vahadi A. Evaluation of new gingival retraction agents. J Dent Res 1991; 70(11): 1447-49. 